\title{
Guns, Cowboys, Philadelphia Mayors, and Civic Republicanism: On Sanford Levinson's The Embarrassing Second Amendment
}

\author{
Wendy Brown $\uparrow$
}

Sanford Levinson's reading of the Second Amendment deftly parlays a strategy of historical interpretation into an opening move in a much needed contemporary political conversation about guns, individual rights, popular sovereignty, and state power. ${ }^{1}$ This reading suggests an intriguing recovery of the Amendment's origins in republican anti-statism and, in the same gesture, potentially retrieves the political value of the Amendment for those who ordinarily have little in common with its stickiest adherents. Historically situated in the republican concern with popular power, the Second Amendment might be less the individualistic cudgel of National Rifle Association sloganeering than a token and vehicle of collective civic resistance against the domestic imperialism of centralized state power.

However compelling and disturbing several aspects of Levinson's provocative argument may be, I think it is ultimately less republican than it wants to be; I think the republicanism it does harbor is of questionable value; and I think the republican subject, if he exists, is definitely a "he." In what follows, I will suggest that both the republican subject and polity invoked in Levinson's interpretation are, at best, appealing historical figures, of little relevance to our socially fragmented and politically disintegrated mass culture, to our bureaucratized, centralized, and nucleararmed state, or to the relationship between them.

\section{Republican Polity or Liberal State?}

The republican argument for arming the citizenry is most powerfully elaborated not by the English thinkers Levinson cites, but in that passionate republican work, Machiavelli's Discourses on the First Decade of Titus Livius. ${ }^{2}$ In Machiavelli's account, terrible ills arise from disarming

\footnotetext{
$\dagger$ Associate Professor, Women's Studies, University of California, Santa Cruz.

1. Levinson, The Embarrassing Second Amendment, 99 Yale L.J. 637 (1989).

2. N. Machiavelli, Discourses on the First Decade of Titus Livius, in 1 The Chief Works AND OTHERs 175, 410-11 (A. Gilbert trans. 1965).
} 
the people to escape an imagined rather than real, danger instead of doing things that would give them security. ${ }^{3}$ His beseeching tone and romantic prose almost make one forget that he is talking about deadly weapons:

The heart and the vital parts of a body should be kept armored, and not the extremities. For without the latter it lives, but when the former is injured, it dies; and these states keep their hearts unarmored and their hands and feet armored. What this error has done to Florence has been seen and is seen every day; and when an army passes her boundaries and comes within them close to her heart, she has no further resource. ${ }^{4}$

What is so compelling in this account is the way Machiavelli links a state's security with the strength and independence of its citizenry. His bodily metaphor suggests a literal weakening of state power when armed citizens do not comprise the heart of the state; when state force is rooted in something other than an empowered citizenry; when state power is without "foundations" in the people; and when the polity is without civic virtù. In fact, Machiavelli is not talking simply about arms, but about the aggregate health of the republican polity. He recognizes that a vigorous, independent citizenry is not at odds with state power but, to the contrary, represents an indispensable source of political flexibility, defense, and renewal. Drawing the connection between freedom and power, both individual and collective, in a manner rivalled only by Marx, Machiavelli is a marvelous antidote to our neo-Hobbesian beliefs that those practices are antinomic.

The problem with Levinson's employment of this feature of republican thought to interpret the Second Amendment is that it is not clear how much it has to do with either our Gonstitution or our present condition. Consider the confusion Levinson identifies in the text of the Amendment-a confusion symptomatic of the recessive position of republicanism in the constitutional formulation of the United States as a liberal polity. ${ }^{5}$ The preambled Second Amendment is ambiguous about whether it grants citizens the right to bear arms for protection of the state, ${ }^{6}$ against the state, ${ }^{7}$ or against one another. ${ }^{8}$ Levinson calls "republican" an argument that our right to bear arms is protection against the state's potentially excessive use of its prerogative, but this argument does not really express a republican sensibility. Rather, it signifies a liberal overtaking of such sensibilities. Machiavelli's republican citizenry is not armed against the

\footnotetext{
3. Id. at 410 .

4. Id. at 411 .

5. See Levinson, supra note 1, at 643-44.

6. See, e.g., id. at 644-45 (Levinson's discussion of state militias).

7. See, e.g., id. at 648-51, 656-57 (Levinson's discussion of resistance to governmental tyranny).

8. See, e.g., id. at 655-56 (Levinson's discussion of NRA and vigilantism; emphasis that citizens should participate in law enforcement).
} 
state but as the state-an armed citizenry is the state's heart, not its opposition or counterweight. Levinson's view of the Second Amendment as citizen protection against the state assumes a cleavage if not a hostile antagonism between state and society: "Consider the possibility . . . that the ultimate 'checking value' in a republican polity is the ability of an armed populace, presumptively motivated by a shared commitment to the common good, to resist governmental tyranny." "In contrast to Machiavellian republicanism, Levinson's formulation is really a militarized version of Locke's "appeal to heaven"10 and a far cry from armoring the heart of a polity. This is not republicanism but a kind of bastardized liberalism, in which a diffident and depoliticized populace squares off against the state, in which there is no political heart at all but only hands and head and feet all armed against one other.

\section{Republican Citizens or Liberal Individuals?}

We may pose two sets of questions about the place held by the republican subject in Levinson's argument. First, upon what kind of political subject is republicanism premised, and what kind do we have today? What does it mean to make appeals to a republican political order when we do not have one, when our citizenry is not republican in character, values, or practices? The republican link between arms, freedom, and civic virtue (and virtù) depends upon the existence of responsible, active, public-minded citizens bound together in at least a modicum of civic solidarity. Machiavelli's passionate plea is not on behalf of the liberal individual-acquisitive, privatistic, concerned with hunting quail, protecting his property, or defending rights to his woman-but the republican citizen oriented toward civic, public life. And arming our citizenry, or defending our individual right to bear arms, will hardly transform us into such citizens. While Levinson's armed populace is "presumptively motivated by a shared commitment to the common good,"11 I cannot imagine a less appropriate appellation for the contemporary American citizenry, which bears a shared commitment to almost nothing, least of all a common good. Ensuring the individual right to bear arms surely will not infuse the citizenry with such commitment.

The second set of questions Levinson's argument raises about the republican subject pertains to freedom. What kind of freedom does this subject claim: What kind of freedom is republican freedom? At the very least we might investigate, although Levinson does not, the classical republican links between force and freedom, arms and freedom, violence and freedom. Might there be something a bit "gendered" about a formulation of

9. Id. at 648 .

10. J. Locke, Two Treatises of Government 300 (P. Laslett $2 \mathrm{~d}$ ed. 1967) (3d ed. 1698).

11. Levinson, supra note 1 , at 648 . 
freedom that depicts man, collectively or individually, securing his autonomy, his woman, and his territory with a gun - a formulation signified in our epoch by Eugene Hasenfus flying over the forests of Central America, presidential review of the men in uniform charged with defending our freedom, or Ollie North's good intentions? Might there be something in this construction that seeks to banish the fragile, perishable feature of political freedom, something that reveals this construction's socially male as well as colonial character-subduing with force what it cannot discursively persuade, tame, or cohabit the universe with, and possessing with force what it cannot seduce? Might the republican formulation of freedom, for all its appeal next to liberalism, contain some ills in its genderbiased, imperial, and propertied moments, and might the express link between guns and freedom betoken such moments?

\section{Storming the Pentagon}

Let us consider the other side of the political relationship upon which Levinson's republican interpretation of the Second Amendment depends, the problem of the state. Levinson writes:

I do not want to argue that the state is necessarily tyrannical; I am not an anarchist. But it seems foolhardy to assume that the armed state will necessarily be benevolent. The American political tradition is, for good or ill, based in large measure on a healthy mistrust of the state. $^{12}$

I agree that tyranny is not our problem today. But tyranny is not the only, nor most significant, mode of the contemporary state's aggression against its people or abuse of the people's trust. Indeed, bureaucratic rationalization and discipline, deregulated toxic production and dumping, arbitrary changes in welfare policy, and the Iran-Contra or HUD scandals are more significant instances of anti-democratic state arrogations of power. It is quite difficult to see how the Second Amendment empowers the citizenry to prevent these things. Even when we narrow our focus to state abuses of what Weber termed its legitimate monopoly of violence, ${ }^{13}$ it is far from clear that an armed citizenry is a viable mode of resistance to these abuses. Think about Kent State, or more routine police brutality in breaking up militant demonstrations or arresting and interrogating America's nonprivileged and nonwhite. Or, think about the MOVE crisis in Philadelphia several years ago, in which the state literally bombed civilian households. What exactly does a republican version of our right to bear arms offer us here? The MOVE household had a cache of weapons.

12. Id. at 656 .

13. M. Weber, Politics as a Vocation, in From Max Weber: Essays in Sociology 78 (H. Gerth \& C. Mills trans. 1958). 
The mayor of Philadelphia had a bomb. Wherein lies the freedom or the republican virtue in this relationship? Of what serious value are handguns or even machine guns against the arsenal of the modern state? For that matter, of what serious assistance are handguns and machine guns for the defense of the state in a nuclear age? If the state militia component of the Amendment remains anything more than history, we would be wise to consign it to history through a domestic nuclear non-proliferation treaty.

If we are then left with participation in law enforcement as the sole republican rationale for arming the people, it surely requires little reflection to discern why the Guardian Angels, those most remarkable selfappointed protectors of the peace, do not carry deadly weapons, nor why the British have for so long held out against equipping their bobbies with firearms.

\section{Whose Right, Whose VIOLATION?}

Finally, what does it mean to speak about the Second Amendment in the language of either republicanism or liberalism when the most routine victims of this "right" are outside both discourses: urban Black men between the ages of sixteen and thirty-four, for whom homicide is the leading cause of death, and women, one of whom is raped every six minutes, one out of three times at gunpoint or knifepoint. When our privately held deadly weapons are aimed neither at the state nor the lawless, but at the most marginal or violable strata of our population, is there anything more than quaintness to a republican justification of our right to bear arms?

In short, Levinson's vision of an armed citizenry, collectively resisting the excesses of state power on behalf of itself as a community, is at best nostalgic, and at worst dangerously naive and no little bit sexist in its predication upon "a world we have lost." Levinson may be partly right in the historical argument, but the history is now largely irrelevant, not merely to our present condition, but to the prospects for reviving citizenship, public life, meaningful freedom, or political community in the United States. We cannot become republican citizens nor create a republican polity by arming ourselves or defending our right to do so, and it is irresponsible to make arguments about the relationship between arms and liberty as if we did not live in a nuclear era, an era of thoroughly disintegrated public life and disintegrating social order, and an era of rampant violence within and against the urban poor and against women of all socio-economic classes. I want to be very clear here: Like Levinson, I would prefer a republican order to a liberal-capitalist one. But we do not have a republican political order; we are not a republican citizenry; we do not have republican institutions, values, virtues, or arrangements of power. And we cannot generate a republican order merely by interpreting our Constitution through a republican hermeneutic scheme. Moreover, 
even within republicanism, we do not have to swallow it whole. The republican intellectual tradition includes a militarism, elitism, and machismo that is past due for thoughtful critique and reworking.

Levinson began his article by mapping different stories about the Constitution and the Second Amendment. I also want to conclude with a story, yet another way of mapping our differences as citizens in relationship to this Amendment. Last summer I came out of a week-long trek in the Sierra Nevada to discover that the car my friends and I had parked at the trailhead would not start. Still deep in the wilderness, thirty miles from a paved road or gas station, I was thrilled to see signs of human life in a nearby Winnebago. These life signs turned out to be a California sportsman making his way through a case of beer, flipping through the pages of a porn magazine, and preparing to survey the area for his hunting club in anticipation of the opening of deer season. Not feeling particularly discriminating, I enlisted his aid (and fully charged battery). While his buddy and my three looked on, together we began working on getting the car started, a project that consumed our attention and combined sets of tools for the next two hours.

In the course of our work, there was time to reflect upon much in our happenstance partnership. My rescuer was wearing a cap with the words "NRA freedom" inscribed on it. This was, I thought at the time, perfectly counterpoised to the injunction "Resist Illegitimate Authority" springing from my tee shirt (a token of my involvement with a progressive political foundation called RESIST). The slogans our bodies bore appeared to mark with elegant economy our attachment to opposite ends of the political and cultural universe-he preparing to shoot the wildlife I came to revere, he living out of his satellite-dished Winnebago and me out of my dusty backpack, he sustained by his guns and beer, me by my Nietzsche and trail mix.

Levinson's The Embarrassing Second Amendment made me rethink this assessment and consider whether for all our differences, we may have shared a commitment to resisting illegitimate authority and perhaps even occupied a shared historical tradition in this respect-one that prefers an empowered people to a state monopoly on power. However, upon still futher reflection, I remember something that gives me pause about moving to a conclusion that I shared much of anything with this man or that I needed to defend his guns as part of a politics of resisting illegitimate authority. It occurred to me then, and now, that if I had run into him in those woods without my friends or a common project for us to work on, I would have been seized with one great and appropriate fear: rape. During the hours I spent with him, I had no reason to conclude that his respect for women's personhood ran any deeper than his respect for the lives of Sierra deer, and his gun could well have made the difference between an assault that my hard-won skills in self-defense could have fended off and 
one against which they were useless. And when I consider that scene, I wonder again about the gendered constitutional subject, about shifting Levinson's cognitive mapping from a focus on the differences between an ACLU member and a New Right devotee to the differences between the social positioning and experiences of men and women in our culture. Who is the gun-carrying citizen-warrior whose power is tempered by a limit on the right to bear arms? Is he most importantly a republican citizen, or more significantly, a socially male one? Is his right my violation, and might his be precisely the illegitimate authority I am out to resist? 
